\title{
Vertical and temporal variation in phytoplankton assemblages correlated with environmental conditions in the Mundaú reservoir, semi-arid northeastern Brazil
}

\author{
LIRA, GAST. ${ }^{a}$, MOURA, AN. ${ }^{a}$, VILAR, MCP. ${ }^{a}$, CORDEIRO-ARAÚUO, MK. ${ }^{a, b}$ and \\ BITTENCOURT-OLIVEIRA, MC. ${ }^{a, b *}$ \\ ${ }^{a}$ Graduating Program on Botany, Rural and Federal University of Pernambuco - UFRPE, Rua D. Manoel de Medeiros, \\ s/n, Dois Irmãos, CEP 52171-030, Recife, PE, Brazil \\ bDepartment of Biological Sciences, Luiz de Queiroz College of Agriculture, University of São Paulo - USP, \\ Av. Pádua Dias, 11, São Dimas, CEP 13418-900, Piracicaba, SP, Brazil \\ *e-mail: mbitt@usp.br
}

Received: January 21, 2013 - Accepted: July 31, 2013 - Distributed: November 30, 2014

(With 4 figures)

\begin{abstract}
The goal of this study was to analyse the vertical structure of the phytoplankton community at the Mundaú reservoir, located in the semi-arid region of northeastern Brazil, and to correlate it to environmental conditions over two distinct seasons, dry and rainy. Samples were collected bimonthly at eight depths in the dry and rainy season for analyses of the physical and chemical variables of the water, as well as density, abundance, dominance, species diversity index and equitability of the community. Analysis of variance (ANOVA-two way) was used to analyse the vertical and seasonal differences, and Canonical Correspondence Analysis (CCA) was used to assess associations between phytoplankton and environmental variables Cylindrospermopsis raciborskii (Woloszynska) Seenaya and Subba Raju was the only dominant species and Geitlerinema amphibium (C. Agardh) Anagnostidis, Merismopedia punctata Meyen and Synedra rumpens Kützing. Others six taxa were abundant in at least one of the samples. Distinct vertical distribution patterns were observed for the abundant taxa between depths and seasons. The cyanobacteria, with the exception of C. raciborskii, showed similar seasonal patterns, with higher densities in the dry season. The CCA showed a strong correlation between the density of the phytoplanktonic species and abiotic variables. The vertical changes in abundant taxa revealed distinct patterns regulated by the variation in the environmental factors that were directly linked to seasonality, with the success of one or more species being dependent on their life strategies and ecological needs. The present study restates the importance of environmental and seasonal factors for phytoplankton composition and distribution in a freshwater tropical reservoir through a vertical gradient.
\end{abstract}

Keywords: freshwater, microalgae, seasonality, spatial dynamics, tropical region

\section{Variações vertical e temporal nas assembleias fitoplanctônicas correlacionadas com condições ambientais no reservatório Mundaú, semiárido do nordeste do Brasil}

\section{Resumo}

O objetivo deste estudo foi avaliar a estrutura vertical da comunidade fitoplanctônica no reservatório Mundaú localizado na região semiárida do nordeste do Brasil e correlacioná-la com as condições ambientais durante dois períodos sazonais distintos, seca e chuva. Amostras foram coletadas bimensalmente em oito profundidades em duas estações climáticas, seca e chuvosa para análises de variáveis físicas e químicas da água, bem como, da densidade, abundância, dominância, índice de diversidade especifica e equitabilidade da comunidade. Análise de variância (ANOVA - dois critérios) foi usada para avaliar as diferenças vertical e sazonal e Análise de Correspondência Canônica (CCA) as associações entre o fitoplâncton e variáveis ambientais. Cylindrospermopsis raciborskii (Woloszynska) Seenaya and Subba Raju foi a única espécie dominante e Geitlerinema amphibium (C. Agardh) Anagnostidis, Merismopedia punctata Meyen e Synedra rumpens Kützing, foram abundantes em ambas as estações. Outros seis táxons foram abundantes em, pelo menos, uma das amostras. Distintos padrões de distribuição vertical foram observados para os táxons abundantes entre as profundidades e estações. As cianobactérias, com exceção de C. raciborskii, apresentaram padrão sazonal similar com maiores densidades no período seco. A CCA mostrou uma correlação entre a densidade das espécies fitoplanctônicas e as variáveis ambientais. As mudanças verticais nos táxons abundantes revelaram distintos padrões regulados pela 
variação nos fatores ambientais que estiveram diretamente ligados à sazonalidade, sendo assim, o sucesso de uma ou mais espécie está ligado à sazonalidade, às suas estratégias de vida e às suas necessidades ecológicas. O presente estudo corrobora a importância de fatores ambientais e sazonal na composição e distribuição do fitoplâncton ao longo de um gradiente vertical em um reservatório de água doce de região tropical.

Palavras-chave: água doce, microalga, sazonalidade, dinâmica espacial, região tropical.

\section{Introduction}

The phytoplankton community is an important biological component of water bodies, because it is responsible for a large part of the primary production, constituting a food chain basis. From currently published estimates for land plants and for coastal vegetation, the production of phytoplankton accounts for nearly $50 \%$ of the global net primary production (Field et al., 1998; Salmaso et al., 2012).

The phytoplankton distribution and structure are strongly related to the physical and chemical features of water bodies. Variations of abiotic water conditions occur naturally throughout the day and over the seasons of the year. These variations can be either vertical or horizontal and may be closely related to stratification and mixing of the water column, resulting in changes in the availability of light and nutrients for the development of the phytoplankton community (Lopes et al., 2005). Other factors such as herbivory, internal seiches, turbulence and water renewal rate may also influence the vertical distribution of the phytoplankton (Litchman et al., 2010; Mellard et al., 2011). Associated to these conditions, sewage discharge, agricultural and industrial waste, is constantly released into water bodies, leading to eutrophication of the water, changing the phytoplankton structure and enabling an uncontrolled increase in some populations such as cyanobacteria. The excessive development of the biomass of these organisms (blooms), which often produce toxins, results in an unpleasant taste and odor of the water, affecting the availability of drinking waters, and leads to loss of environmental scenic characteristics compromising thereby its quality for the most varied uses (Heo and Kim, 2004; Salmaso et al., 2012).

Reservoirs located in semiarid regions of northeastern Brazil are used for public water supply as well as recreation, irrigation, fishing, farming of aquatic organisms and other uses (Bittencourt-Oliveira et al., 2011, 2012; Moura et al., 2011). The climate of this region has limited rainfall and a high degree of evaporation, which favours considerable variation in the abiotic characteristics of the aquatic ecosystems, thereby influencing the distribution and growth of phytoplankton communities (Chellappa and Costa, 2003). Thus, understanding the dynamics of these organisms is of fundamental importance to optimise the use and management of these aquatic ecosystems.

The tropical Mundaú reservoir is an important public water supply located in the northeastern region of Brazil. This reservoir receives a large amount of polluting material and has frequent blooms of cyanobacteria (BittencourtOliveira et al., 2011). The goal of this study was to analyse the vertical structure of phytoplanktonic communities in the Mundaú reservoir, northeastern Brazil and correlate it to environmental conditions over two distinct seasons.

\section{Material and Methods}

\subsection{Study area and sampling procedure}

The Mundaú reservoir is located in the city of Garanhuns ( $8^{\circ} 55^{\prime} 40^{\prime \prime} \mathrm{S}$ to $8^{\circ} 57^{\prime} 04^{\prime \prime} \mathrm{S}$ and $36^{\circ} 30^{\prime} 40^{\prime \prime} \mathrm{W}$ to $\left.36^{\circ} 29^{\prime} 02^{\prime \prime} \mathrm{W}\right), 716 \mathrm{~m}$ above sea level, in the state of Pernambuco (northeastern Brazil). The reservoir has an area of $4 \mathrm{~km}^{2}$ and accumulation capacity of approximately $1.9 \times 10^{6} \mathrm{~m}^{3}$ with mean depth of $11 \mathrm{~m}$. It is used for fishing, irrigation and is the water supply for about 120 thousand inhabitants (Pernambuco, 2000). The geographical region is characterised climatologically by a dry season from August to January and a rainy season from February to July. Over the study period the air temperature ranged from $20.2^{\circ} \mathrm{C}$ to $22.5^{\circ} \mathrm{C}$ in the dry season and from $18.9^{\circ} \mathrm{C}$ to $23.4^{\circ} \mathrm{C}$ in the rainy season; wind direction and speed were instable in the dry season, alternating between southeasterly, easterly and northeasterly; in the rainy season, the wind direction alternated between southerly and northeasterly. Monthly precipitation ranged from $4.1 \mathrm{~mm}$ to $62.7 \mathrm{~mm}$ in the dry season and from $115.8 \mathrm{~mm}$ to $161.1 \mathrm{~mm}$ in the rainy season.

Sampling was carried out between January and November 2006, during two seasonal periods: dry (January, September and November) and rainy (March, May and July). The water samples were collected with van Dorn bottles in the limnetic region at eight depths defined on the basis of indirect calculation of the vertical light attenuation coefficient (Poole and Atkins, 1929) $\left(\mathrm{K}=1.7 / \mathrm{Z}_{\mathrm{ds}}\right)$ : a) surface (100\% available light); b) $0.5 \mathrm{~m}$; c) $1.0 \mathrm{~m}$; d) $2.0 \mathrm{~m}$; e) $4.0 \mathrm{~m}$; f) $6.0 \mathrm{~m}$ (to $1 \%$ available light); g) $8.0 \mathrm{~m}$; and h) $9.0 \mathrm{~m}$ (total absence of light).

\subsection{Abiotic and biotic variables}

Water temperature and dissolved oxygen were determined using an oximeter (Schott Glaswerke Mainz, Handylab OX1), turbidity (NTU) with a turbidimeter (Hanna Instruments, $\mathrm{HI}$ 93703), pH, electrical conductivity $\left(\mu \mathrm{S} . \mathrm{cm}^{-1}\right)$ and total dissolved solids $\left(\mathrm{mg} . \mathrm{L}^{-1}\right)$ were accessed with a field YSI device (model 556) in situ. Samples for biological and nutrient analysis (total nitrogen and total phosphorus) were collected with a van Dorn bottle.

The determination of total phosphorus and total nitrogen was based on the procedure described by Valderrama (1981). For the study of phytoplankton, $100 \mathrm{~mL}$ aliquots $(n=3)$ were stored in plastic bottles and preserved with Lugol acetic acid. These were analysed under an optical Zeiss Jenaval microscope coupled with a measuring ocular to analyse the morphological characteristics of the species, 
which were used for taxonomic identification using keys available in books and specialised articles. Quantification was performed using Utermöhl methods (Utermöhl, 1958) with an inverted microscope (Zeiss, Axiovert). Abundance and dominance were determined from the density data, following Lobo and Leighton (1986). Species diversity index (bits.cell ${ }^{-1}$ ) were accessed using Shannon and Weaver (1948) and equitability were calculated using Pielou (1977). The monthly data were used as repetitions of the climatic seasons and presented as the mean for each period.

Analysis of variance (ANOVA two-way) was used to test differences in abiotic factors $(p<0.05)$ between depths and for different seasons using the BioEstat 5.0 software (Ayres et al., 2003). Canonical Correspondence Analysis (CCA) was used to assess associations between phytoplankton and environmental variables. The matrix with biotic data was constructed only with species abundant in at least one sample. Significance $(p<0.05)$ was tested with the Monte Carlo test, with 999 unrestricted permutations using the Canoco 4.5 program.

\section{Results}

Stratification was observed in the Mundaú reservoir over both seasons (Figure 1a, e). Smaller thermal stratification was found in the rainy season (Figure 1). In both seasons, the epilimnion occurred at $2.0 \mathrm{~m}$ while the hypolimnion started at $6.0 \mathrm{~m}$. The reservoir shows stratified dissolved oxygen levels throughout the whole study, with clinograde patterns. The $\mathrm{pH}$ ranged from slightly acid to alkaline in the dry season (Figure 1c) and was neutral to alkaline in the rainy season (Figure $1 \mathrm{~g}$ ). There was no significant difference in total nitrogen and phosphorous, both vertically and seasonally, however, in both seasons the highest concentrations were generally recorded at the bottom (Figures 1d, h). Significant differences between the dry and rainy season were observed for temperature $(\mathrm{F}=11.76$, $p=0.01)$, dissolved oxygen $(\mathrm{F}=12.69, p=0.009),(\mathrm{F}=98.66$, $p=0.0001), \mathrm{pH}(\mathrm{F}=12.05, p=0.01)$ and total dissolved solids $(\mathrm{F}=333.52, p<0.0001)$. Significant differences were observed between depths for temperature $(\mathrm{F}=71.37$, $p<0.0001)$, dissolved oxygen $(\mathrm{F}=31.46, p=0.0003)$ and $\mathrm{pH}(\mathrm{F}=43.74, p=0.0002)$.

Seventy-one taxa distributed in six classes were identified. The Chlorophyceae Class was the richest species throughout the study and, together with cyanobacteria, accounted for $83.10 \%$ of the community (Table 1 ). Density variations were observed between different sampling depths (vertical variation), with a greater density of organisms down to a depth of $2.0 \mathrm{~m}$ (Figure 2 ). The mean density was higher in the rainy season (Figure 2b). Cyanobacteria and Bacillariophyceae showed the greatest densities.
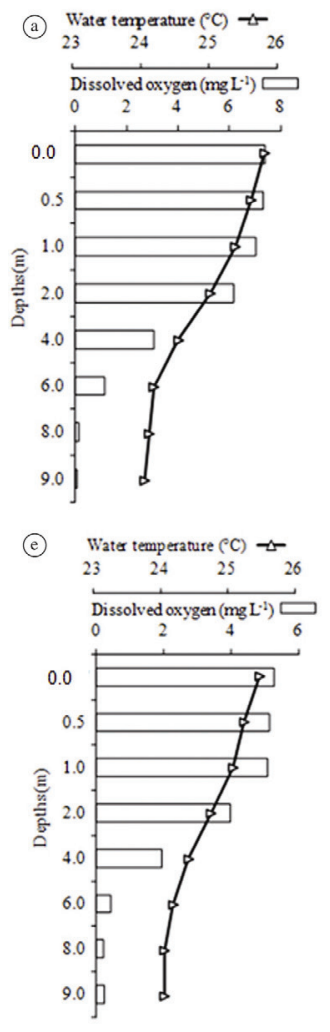
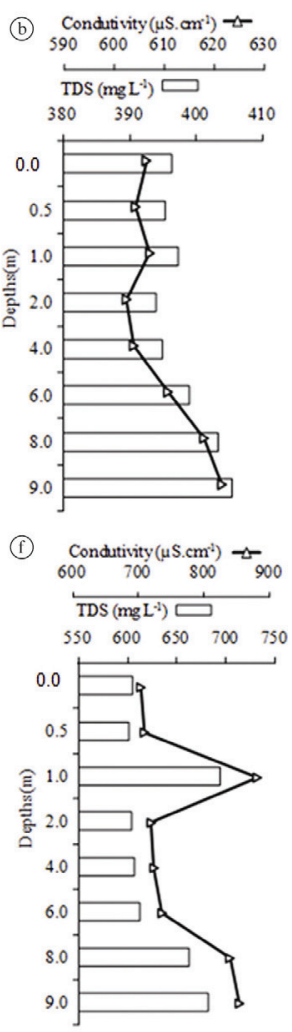

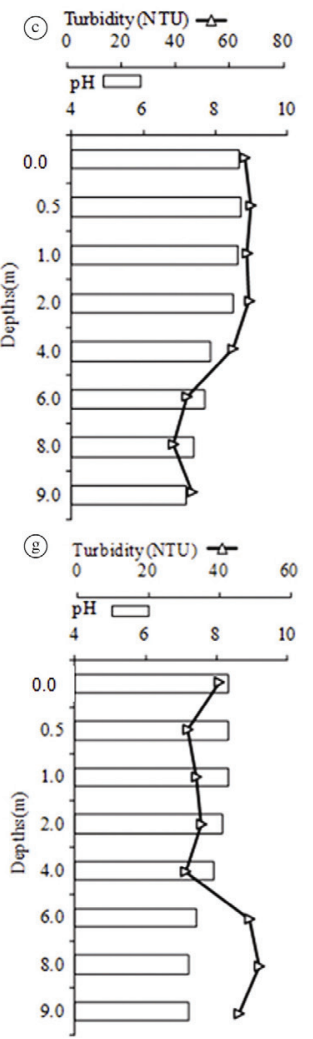

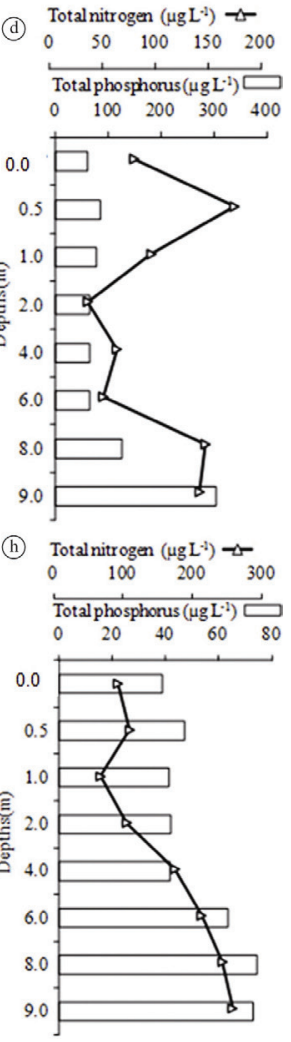

Figure 1. Variation of abiotic variables in Mundaú reservoir, state of Pernambuco, Brazil, in the dry season and rainy season at different depths. (a-d). Dry season; (e-h). Rainy season. (a). Water temperature and dissolved oxygen; (b). Conductivity and Total Dissolved Solids; (c). Turbidity and pH; (d). Total nitrogen and total phosphorus; (e). Water temperature and dissolved oxygen; (f). Conductivity and Total Dissolved Solids; (g). Turbidity and pH; (h). Total nitrogen and total phosphorus. 
Table 1. Taxonomic summary and occurrence of the phytoplanktonic taxa at the Mundaú reservoir, state of Pernambuco, Brazil in the rainy and dry seasons at different depths (metres). 0.0, 0.5, 1.0, 2.0, 4.0, 6.0, 8.0, 9.0; Ad: all depths; - : absence of taxa.

\begin{tabular}{|c|c|c|}
\hline \multirow{2}{*}{ Taxa } & \multicolumn{2}{|c|}{ Seasons } \\
\hline & Dry & Rainy \\
\hline \multicolumn{3}{|l|}{ CYANOBACTERIA } \\
\hline Anabaena constricta (Szafer) Geitler & $6.0 ; 8.0$ & $4.0 ; 6.0 ; 8.0 ; 9.0$ \\
\hline Aphanocapsa sp. & Ad & Ad \\
\hline Chroococcus limneticus Lemmermann & $0.5 ; 1.0 ; 2.0 ; 4.0 ; 6.0 ; 8.0 ; 9.0$ & Ad \\
\hline Chroococcus minimus (Keissler) Lemmermann & Ad & Ad \\
\hline Chroococcus minutus (Kützing) Nägeli & Ad & Ad \\
\hline Chroococcus turgidus (Kützing) Nägeli & Ad & Ad \\
\hline $\begin{array}{l}\text { Cylindrospermopsis raciborskii (Woloszynska) } \\
\text { Seenayya and Subba Raju }\end{array}$ & Ad & Ad \\
\hline $\begin{array}{l}\text { Geitlerinema amphibium (C. Agardh ex Gomont) } \\
\text { Anagnostidis }\end{array}$ & Ad & Ad \\
\hline Lyngbya sp. & 1 & 9 \\
\hline Merismopedia punctata Meyen & Ad & Ad \\
\hline Merismopedia minima Beck & Ad & Ad \\
\hline Microcystis aeruginosa (Kützing) Kützing & Ad & Ad \\
\hline Microcystis flos-aquae (Wittrock) Kirchner & Ad & - \\
\hline Microcystis robusta (Clark) Nygaard & 9 & Ad \\
\hline Microcystis wesenbergii (Komárek) Komárek & Ad & Ad \\
\hline Oscillatoria princeps Vaucher ex Gomont & $0.0 ; 0.5 ; 1.0 ; 4.0 ; 6.0 ; 8.0$ & $6.0 ; 8.0$ \\
\hline Phormidium sp. & Ad & - \\
\hline Pseudanabaena sp. & Ad & Ad \\
\hline Radiocystis sp. & - & 6.0 \\
\hline Spirulina sp. & - & $0.5 ; 8.0$ \\
\hline Synechocystis sp. & 9.0 & Ad \\
\hline \multicolumn{3}{|l|}{ BACILLARIOPHYCEAE } \\
\hline Aulacoseira granulata (Ehrenberg) Simonsen & $0.0 ; 9.0$ & - \\
\hline Cyclotella meneghiniana Kützing & $6.0 ; 8.0 ; 9.0$ & - \\
\hline Nitzschia sp. & Ad & Ad \\
\hline Ulnaria ulna (Nitzsch) P. Compère & Ad & Ad \\
\hline Synedra rumpens Kützing. & Ad & Ad \\
\hline \multicolumn{3}{|l|}{ CHLOROPHYCEAE } \\
\hline Actinastrum hantzschii Lagerheim & 2.0 & - \\
\hline Ankistrodesmus bibraianus (Reinsch) Korshikov & $1.0 ; 4.0$ & 1.0 \\
\hline Ankistrodesmus gracilis (Reinsch) Korshikov & - & 4.0 \\
\hline Chlamydomonas sp. & $2.0 ; 4.0$ & $0.0 ; 0.5 ; 1.0 ; 2.0 ; 4.0$ \\
\hline Chlorella vulgaris Beijerinck & Ad & Ad \\
\hline Closterium sp. & Ad & $0.5 ; 1.0 ; 4.0 ; 6.0 ; 8.0 ; 9.0$ \\
\hline Coelastrum astroideum De Notaris & $0.5 ; 1.0 ; 2.0 ; 4.0 ; 8.0$ & $0.0 ; 0.5 ; 1.0 ; 2.0 ; 4.0$ \\
\hline Coelastrum microporum Nägeli & $0.0 ; 0.5 ; 6.0 ; 8.0 ; 9.0$ & $0.0 ; 0.5 ; 1.0 ; 6.0 ; 9.0$ \\
\hline Coelastrum sphaericum Nägeli & 1.0 & - \\
\hline Crucigenia fenestrata (Schimidle) Schimidle & $0.5 ; 8.0$ & $0.0 ; 4.0 ; 9.0$ \\
\hline Crucigenia quadrata Morren & - & $0.5 ; 1 ; 2 ; 4 ; 6 ; 8 ; 9$ \\
\hline Crucigenia tetrapedia (Kirchner) Kuntze & $0.0 ; 0.5 ; 1.0 ; 2.0 ; 4.0$ & - \\
\hline Dictyosphaerium pulchellum Wood & $1.0 ; 4.0 ; 8.0 ; 9.0$ & $0.0 ; 1.0$ \\
\hline Golenkinia radiata Chodat & Ad & $0.5 ; 1.0 ; 2.0 ; 6.0$ \\
\hline Kirchneriella lunaris var. irregularis G.M. Smith & Ad & Ad \\
\hline Kirchneriella lunaris (Kirchner) K. Möbius & Ad & Ad \\
\hline Kirchneriella obesa (West) West and G.S. West & Ad & Ad \\
\hline Micractinium pusillum Fresenius & Ad & $0.0 ; 2.0 ; 4.0 ; 6.0$ \\
\hline
\end{tabular}


Table 1. Continued...

\begin{tabular}{|c|c|c|}
\hline \multirow{2}{*}{ Taxa } & \multicolumn{2}{|c|}{ Seasons } \\
\hline & Dry & Rainy \\
\hline Monoraphidium arcuatum (Korshikov) Hindák & Ad & Ad \\
\hline $\begin{array}{l}\text { Monoraphidium contortum (Thuret) Komárkova- } \\
\text { Legnerová }\end{array}$ & Ad & Ad \\
\hline $\begin{array}{l}\text { Monoraphidium griffithii (Berkeley) Komárková- } \\
\text { Legnerová }\end{array}$ & Ad & Ad \\
\hline Phythelios viridis Frenzel & 0.0 & 0.0 \\
\hline Planktosphaeria gelatinosa G.M. Smith & Ad & Ad \\
\hline Scenedesmus acuminatus (Lagerheim) Chodat & Ad & Ad \\
\hline Scenedesmus arcuatus (Lemmermann) Lemmermann & 0.0 & - \\
\hline Scenedesmus bicaudatus Dedusenko & Ad & Ad \\
\hline Scenedesmus bijugus (Turpin) Lagerheim & $0.0 ; 0.5 ; 1.0 ; 2.0 ; 4.0 ; 6.0 ; 9.0$ & $0.5 ; 1.0$ \\
\hline Scenedesmus denticulatus Lagerheim & $1.0 ; 2.0 ; 4.0 ; 9.0$ & $0.5 ; 6.0 ; 8.0 ; 9.0$ \\
\hline Scenedesmus quadricauda (Tupin) Brébisson & Ad & Ad \\
\hline $\begin{array}{l}\text { Scenedesmus quadricauda var. quadrispina (Chodat) } \\
\text { G.M. Smith }\end{array}$ & - & 1.0 \\
\hline Schroederia sp. & $0.5 ; 2.0 ; 8.0$ & 9.0 \\
\hline Sphaerocystis sp. & Ad & Ad \\
\hline Staurastrum sp. & - & $2.0 ; 6.0$ \\
\hline Tetradesmus wisconsinensis G. M. Smith & 6.0 & - \\
\hline Tetraedron minimum (A. Braun) Hansgirg & Ad & Ad \\
\hline Tetrastrum sp. & - & $0.0 ; 1.0 ; 4.0 ; 6.0 ; 8.0 ; 9.0$ \\
\hline Tetrastrum triangulare (Chodat) Komárek & Ad & $2.0 ; 8.0$ \\
\hline \multicolumn{3}{|l|}{ DINOPHYCEAE } \\
\hline Gymnodinium sp. & $0.5 ; 1.0 ; 2.0$ & $0.5 ; 1.0 ; 9.0$ \\
\hline Peridinium sp. & - & $0.5 ; 1.0 ; 2.0 ; 4.0 ; 6.0 ; 8.0$ \\
\hline \multicolumn{3}{|l|}{ CHRYSOPHYCEAE } \\
\hline Dinobryon sertularia Ehrenberg & 1.0 & - \\
\hline \multicolumn{3}{|l|}{ EUGLENOPHYCEAE } \\
\hline Euglena sp. & Ad & Ad \\
\hline Euglena acus (O.F. Müller) Ehrenberg & - & 2.0 \\
\hline Phacus curvicauda Svirenko & $0.0 ; 2.0$ & Ad \\
\hline Trachelomonas volvocina (Ehrenberg) Ehrenberh & $0.0 ; 0.5 ; 1.0 ; 2.0 ; 4.0 ; 6.0 ; 8.0$ & Ad \\
\hline
\end{tabular}

The species C. raciborskii (Woloszynska) Seenaya \& Subba Raju was the only dominant species and G. amphibium (C. Agardh) Anagnostidis, M. punctata Meyen and S. rumpens Kützing were abundant in both seasons. In addition, another six taxa (Golenkinia radiata Chodat, Merismopedia minima Beck, Microcystis aeruginosa (Kützing) Kützing, M. wesenbergii (Komárek) Komárek, M. robusta (Clark) Nygaard, Pseudanabaena sp.) were abundant in at least one of the samplings.

Distinct vertical distribution patterns were observed for the abundant taxa between depths and for different seasons (Figure 3). Cyanobacteria (Figures 3a-e, g-h), with the exception of $C$. raciborskii (Figure 3f), showed similar seasonal patterns, with larger densities in the dry season. The species diversity index was low for both seasons and the different sampling depths (varying from 1.79-1.97 bits. cell $^{-1}$ in the dry season and from 1.52-1.76 bits.cell ${ }^{-1}$ in the rainy season) and the equitability values were below 0.5 in both seasons (0.47-0.49 in the dry season and 0.39-0.45 in the rainy season), thereby indicating the dominance of populations of one or more species.

In the Canonical Correspondence Analysis, axes 1 and 2 explained $97.4 \%$ of the variability of the biotic data (Table 2 , Figure 4). Environmental variables explained $99.9 \%$ of the total variability of the biotic data, $98.4 \%$ of those explained by the first two axes. There is a strong correlation between the density of phytoplankton species and abiotic variables $(p<0.05)$ (Table 2, Figure 4). Axis 1 showed the vertical variation of the sampling units in the dry season, separating the samples in the superficial layers from the samples at the bottom, as a function of temperature $\left(\mathrm{T}^{\circ} \mathrm{C}\right)$, dissolved oxygen $\left(\mathrm{O}_{2}\right)$ and $\mathrm{pH}$ (Table 2, Figure 4). M. aeruginosa, M. robusta, $C$. raciborskii e $G$. radiata displayed higher biomasses in the dry season. Axis 2 revealed the establishment of two groups, classified according to the dynamics of the abiotic variables in both seasons studied (Table 2, Figure 4). The 

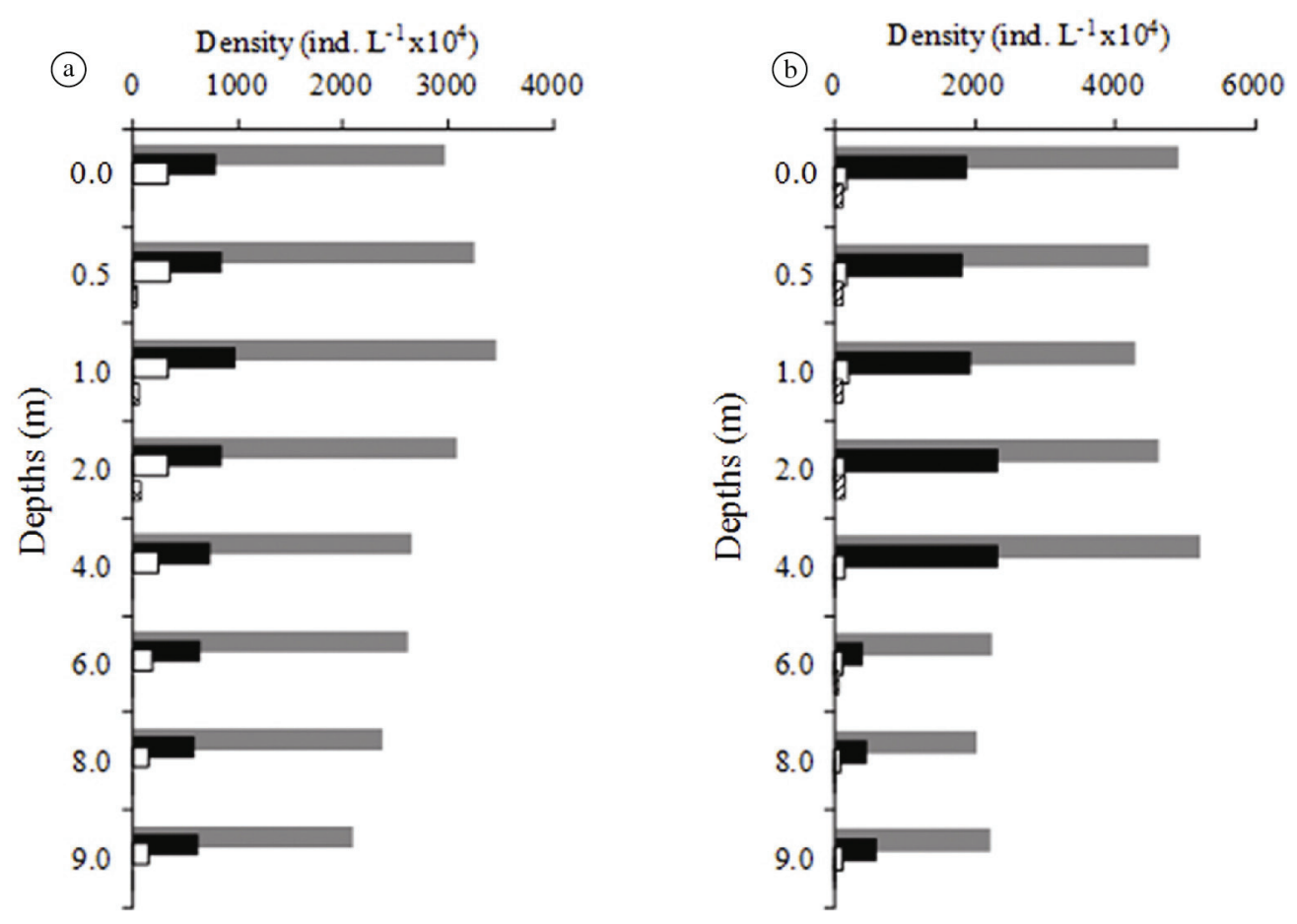

Figure 2. Vertical variation of phytoplankton classes in the Mundaú reservoir, state of Pernambuco, Brazil, in the (a) dry and (b) rainy season. Cyanobacteria ( ); Bacillariophyceae ( ); Chlorophyceae ( ); Dinophyceae ( ); Euglenoplyceae ( ).

first group was formed by the cyanobacteria Merismopedia punctata, C. raciborskii and G. amphibium and by the diatom $S$. rumpens, abundant in the rainy season under conditions of high values of electrical conductivity and total dissolved solids and high concentrations of nitrogen and phosphorus. Characteristics contrary to these revealed the establishment of the second group, formed by the cyanobacteria Merismopedia minima, $M$. aeruginosa, $M$. wesenbergii, M. robusta, and Pseudanabaena sp. and the green microalgae $G$. radiata in the dry season.

\section{Discussion}

For eutrophic tropical reservoirs, water temperature variations, precipitation, wind direction and speed, environment morphometry, and N:P ratios are reported to be the main factors of an aquatic ecosystem, capable of promoting changes in phytoplankton composition and dynamics and the occurrence of cyanobacterial blooms (Chellappa and Costa, 2003; Jöhnk et al., 2008; Delpla et al., 2009).

In the Mundaú reservoir, abiotic variables and seasonality were observed to change the dynamics of phytoplankton and were responsible for the variation in the vertical distribution of the species. Cyanobacteria was the group with the highest density in both seasons studied, showing that the climatological characteristics of the region, as well as the environmental and morphometric characteristics of the ecosystem favour the development of cyanobacteria throughout the year.
Bittencourt-Oliveira et al. (2011) reported that thermal de-stratification in the rainy season favoured the increase in the populations of $C$. raciborskii morphotypes (coiled and straight) by providing more adequate conditions for their growth, namely, lesser light intensity and milder temperatures, which are characteristics of the winter months in the hinterland region of the state of Pernambuco in northeastern Brazil. In the present study, the dominance of this cyanobacterium persisted in the superficial layers of the water column, especially during the rainy season, with consequent low values of species diversity and equitability.

C. raciborskii produces harmful toxins to humans and other animals, also has invasive behaviour and opportunistic characteristics. The success of this cyanobacteria is attributed to its having the ability to fix atmospheric nitrogen, to use internal sources of phosphorus, and high affinity to phosphorus and ammonium and resistance to herbivory by zooplankton, the high capacity for dispersal and low tolerance to low brightness and variations in water temperature (Padisák, 1997; Briand et al., 2002; Berger et al., 2006). Moreover, it has the ability to move in the water column due to the presence of vesicles which give it buoyancy (Reynolds, 1997). According to Walsby (2005), aerotopes allow filaments to remain in the layer with adequate amount of light and nutrients suitable for growth. The greater availability of nutrients and low light in the Mundaú reservoir, as a result of higher rainfall in the rainy season, were important factors that contributed to the increased density of $C$. raciborskii. 


\section{Density (ind. $\mathrm{L}^{-1} \times 10^{4}$ )}

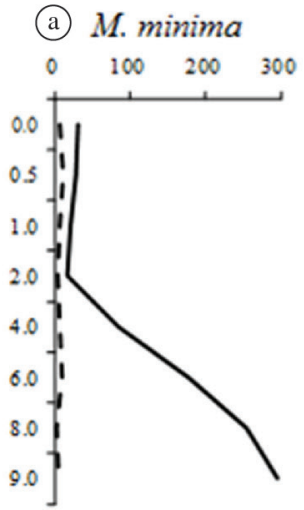

(e) $M$. robusta

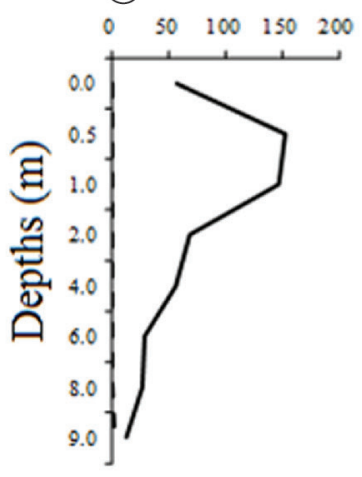

(i) S. rumpens

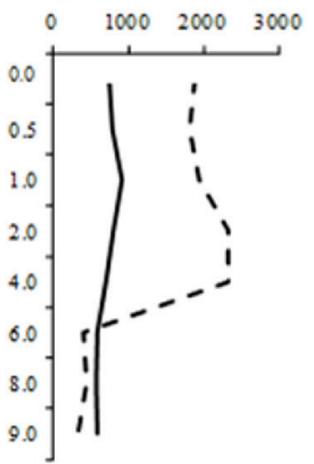

(b) M. punctata
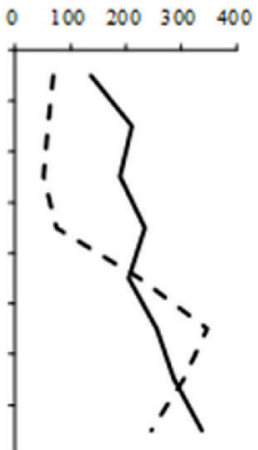

(f) C. raciborskii

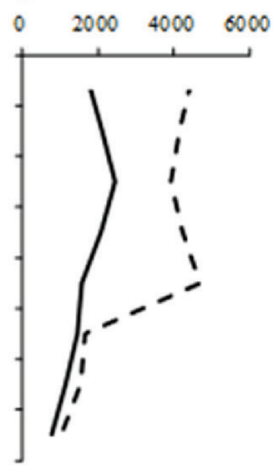

(i) G. radiata

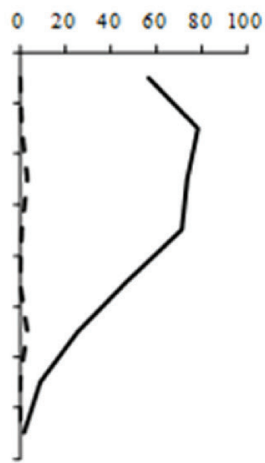

(c) M. aeruginosa - $100 \quad 200 \quad 300 \quad 400$

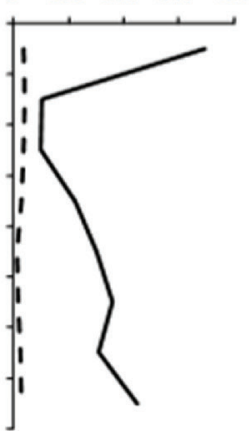

(g) G. amphibium - $200 \quad 400600 \quad 800$

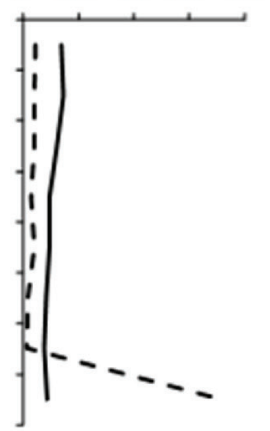

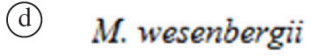

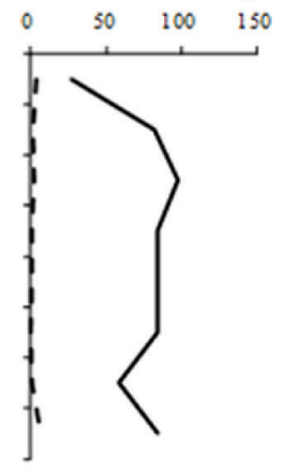

(h) Pseudanabaena sp.

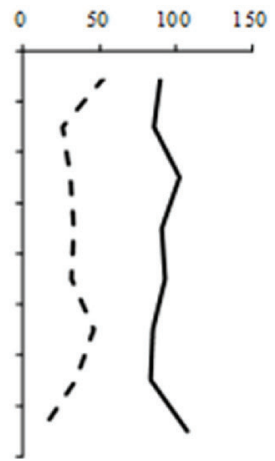

Figure 3. Variation in vertical and seasonal density of abundant species in the Mundaú reservoir, state of Pernambuco, Brazil. . (): Dry season; (): Rainy season.

Padisák (1997) reported that the highest density of C. raciborskii occurs in environments with temperatures above $25^{\circ} \mathrm{C}$, especially in the epilimnion. At Mundaú reservoir, higher densities of this species occurred up to a depth of $2.0 \mathrm{~m}$, limit of the epilimnion in this environment, where higher temperature (between $25^{\circ} \mathrm{C}-26^{\circ} \mathrm{C}$ ), $\mathrm{pH}$ and dissolved oxygen values were observed. Other studies developed both in the natural environment and in the laboratory, show the importance of these variables for the growth of C. raciborskii (Bouvy et al., 2006; Costa et al., 2006; Chellappa et al., 2008).

In tropical reservoirs, differences in temperature of $0.5^{\circ} \mathrm{C}$ between the sub-surface and the bottom promote the formation of stable thermal stratification, with direct influence on the distribution of phytoplankton (Payne, 1986). According to Padisák et al. (1988), sudden variations in temperature, between certain depths, act as a barrier to many phytoplankton species, since they cause changes 
Table 2. Statistical summary and correlation coefficients for phytoplankton and abiotic variables on the first two CCA axes for the Mundaú reservoir, state of Pernambuco, Brazil

\begin{tabular}{lcc}
\hline & Axis 1 & Axis 2 \\
\hline Eigenvalues & 0.253 & 0.014 \\
Accumulated variance in biotic data (\%) & 92.2 & 97.4 \\
Accumulated variance in species-environment relation (\%) & 93.1 & 98.4 \\
Species-environment correlation & 0.999 & 0.993 \\
Monte Carlo test & & \\
Significance of first canonical axis $-p$ & 0.0010 & \\
Significance of all canonical axes $-p$ & 0.0010 & Axis 2 \\
& Intra-set correlation \\
& Axis 1 & -0.4370 \\
Temperature $\left(\mathrm{T}^{\circ} \mathrm{C}\right)$ & -0.7652 & -0.3897 \\
Dissolved oxygen $\left(\mathrm{O}_{2}\right)$ & -0.8454 & 0.0950 \\
Electrical condutivity (Cond) & 0.0564 & -0.4339 \\
pH & -0.8552 & 0.0446 \\
Total dissolved solids (TDS) & 0.0145 & 0.5879 \\
Total nitrogen (TN) & 0.0929 & 0.2643 \\
Total phosphorus total (TP) & 0.6957 & \\
\hline
\end{tabular}

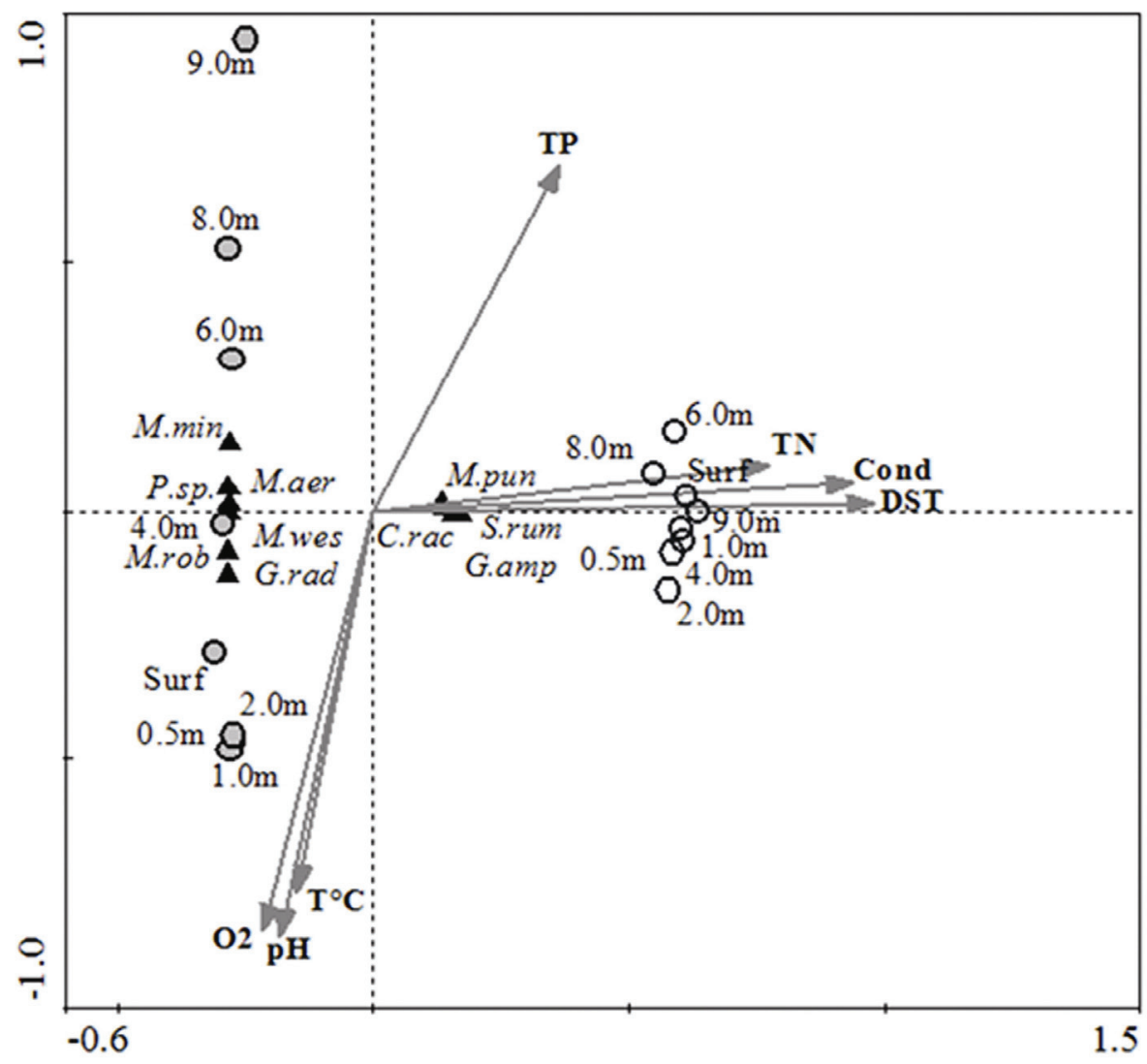

Figure 4. CCA ordination diagram of the sample units in the Mundaú reservoir, state of Pernambuco, Brazil, showing the correlation between phytoplanktonic species and abiotic variables. $\mathrm{T}^{\circ} \mathrm{C}$ : Temperature; $\mathrm{O}_{2}$ : Dissolved Oxygen; Cond: Electrical conductivity; DST: Total dissolved solids; TN: Total nitrogen; TP: Total phosphorous; Surf: Surface; M.pun: Merismopedia punctata; M.min: Merismopedia minima; M.aer: Microcystis aeruginosa; M.wes: Microcystis wesenbergii; M.rob: Microcystis robusta; C.rac: Cylindrospermopsis raciborskii; G.amp: Geitlerinema amphibium; P.sp: Pseudanabaena sp.; S.rum: Synedra rumpens; G.rad: Golenkinia radiata. ( ): Dry season; ( ): Rainy season; ( ): Species. 
in density, viscosity, pressure, oxygen concentration and solubility, and oxygen concentration in the water. Thus, for cyanobacteria such as $C$. raciborskii, buoyancy mechanisms that regulate the position in the water column act as a competitive advantage over other algal groups.

The colonial forms of cyanobacteria of the genus Microcystis also have aerotopes, which would explain the higher density of $M$. aeruginosa and $M$. robusta in the superficial layers of the water column. Microcystis spp. commonly form blooms in rivers, lakes and reservoirs in tropical and temperate regions, which can proliferate to the point that surface waters are covered with thick green scum (Otten et al., 2012). Studies have shown that blooms of Microcystis spp. are often replaced by C. raciborskii (Marinho and Huszar, 2002) and alternation of dominance between these species has been observed, often linked to seasonality (Moschini-Carlos et al., 2009), indicating that there is an overlap of niches which does not permit the occurrence of high densities of both species in the same environment.

Other abundant species in the Mundaú reservoir also showed a preference for specific layers of the water column for growth, such as the preference of species of Merismopedia for regions with low luminosity and temperature, or of Golenkinia radiata for layers closest to the surface.

According to Lindenschmidt and Chorus (1998) and Wolin and Duthie (1999), due to the high rate of sedimentation of diatoms relative to other algal groups, it is necessary for climatological and hydrological events to occur, thus promoting turbulence in the water column, to keep them in suspension. In the Mundaú reservoir isothermy was not observed during the study period, but the lowest stratification recorded in the period of increased rainfall may have contributed to the increased density of S. rumpens. These results show the importance of stratification in the establishment of high densities and dominance of a few phytoplankton species throughout the study.

Overall, seasonal variation has a marked influence on many abiotic parameters in aquatic environments and, as a consequence, the phytoplankton community. In tropical regions, where seasonality is basically defined by a rainy and a dry period, climate change alters precipitation and, as a consequence, the hydrological regime in the neighbouring scenario, inducing deep changes in the input of nutrients. In Mundaú, data on the composition, abundance, dominance, density, diversity index and equitability demonstrate the hypertrophy of the system, with a dominance of Cyanobacteria, especially C. raciborskii. The vertical changes in abundant taxa reveal distinct patterns regulated by the variation of environmental factors that were directly linked to seasonality, with the success of one or more species depending directly on their life strategies and ecological needs.

The present study restates the importance of environmental and seasonality factors in the composition and distribution of phytoplankton in an ecosystem of a tropical region through a vertical gradient.

\section{Acknowledgements}

This research was supported by grants from CNPq (The Brazilian Council for Research and Development - MCBO: 301739/2011-0 and ANM: 302068/2011-2).

\section{References}

AYRES, M., AYRES JUNIOR, M., AYRES, DL. and DOS SANTOS, AA., 2003. Software bioestat, aplicações estatísticas nas áreas das ciências biomédicas. versão 3.0. Belém: Sociedade Civil Mamirauá/MCT/CNPQ.

BERGER, C., BA, N., GUGGER, M., BOUVY, M., RUSCONI, F., COUTÉ, A., TROUSSELLIER, M. and BERNARD, C., 2006. Seasonal dynamics and toxicity of Cylindrospermopsis raciborskii in Lake Guiers (Senegal, West Africa). FEMS Microbiology Ecology, vol. 57, no. 3, p. 355-366. http://dx.doi.org/10.1111/j.15746941.2006.00141.x. PMid:16907750

BITTENCOURT-OLIVEIRA, MC., DIAS, SN., MOURA, AN., CORDEIRO-ARAÚJO, MK. and DANTAS, EW., 2012. Seasonal dynamics of cyanobacteria in a eutrophic reservoir (Arcoverde) in a semi-arid region of Brazil. Revista Brasileira de Biologia = Brazilian Journal of Biology, vol. 72, no. 3, p. 533-544. PMid:22990824.

BITTENCOURT-OLIVEIRA, MC., MOURA, AN., HEREMAN, TC. and DANTAS, EW., 2011. Increase in Straight and Coiled Cylindrospermopsis raciborskii (Cyanobacteria) populations under conditions of thermal de-stratification in a shallow tropical reservoir. Journal of Water Resource and Protection, vol. 3, no. 4, p. 245-252. http://dx.doi.org/10.4236/jwarp.2011.34031.

BOUVY, MA., BA, N., KA, S., SANE, S., PAGANO, M. and ARFI, R., 2006. Phytoplankton community structure and species assemblage succession in a shallow tropical lake (Lake Guiers, Senegal). Aquatic Microbial Ecology, vol. 45, no. 2, p. 147-161. http://dx.doi.org/10.3354/ame045147.

BRIAND, JF., ROBILLOT, C., QUIBLIER-LLOBÉRAS, C., HUMBERT, JF., COUTÉ, A. and BERNARD, C., 2002. Environmental context of Cylindrospermopsis raciborskii (Cyanobacteria) blooms in a shallow pond in France. Water Research, vol. 36, no. 13, p. 3183-3192. http://dx.doi.org/10.1016/ S0043-1354(02)00016-7. PMid:12188114

CHELLAPPA, NT., BORBA, JM. and ROCHA, O., 2008. Phytoplankton community and physical-chemical characteristics of water in the public reservoir of Cruzeta, RN, Brazil. Revista Brasileira de Biologia = Brazilian Journal of Biology, vol. 68, no. 3, p. 477-494. PMid:18833468.

CHELlAPPA, NT. and COSTA, MAM., 2003. Dominant and co-existing species of cyanobacteria from an eutrophicated reservoir of Rio Grande do Norte state, Brazil. Acta Oecologica, vol. 24, supplement 1, p. S3-S10. http://dx.doi.org/10.1016/ S1146-609X(03)00005-5.

COSTA, IAS., AZEVEDO, SMFO., SENNA, PAC., BERNARDO, RR., COSTA, SM. and CHELLAPPA, NT., 2006. Occurrence of toxin-producing cyanobacteria blooms in a Brazilian semiarid reservoir. Brazilian Archives of Biology and Technology, vol. 66, no. 1b, p. 211-219. http://dx.doi.org/10.1590/S1519-69842006000200005. PMid:16710515

DELPLA, I., JUNG, AV., BAURES, E., CLEMENT, M. and THOMAS, O., 2009. Impacts of climate change on surface water quality in relation to drinking water production. Environment International, vol. 35, no. 8, p. 1225-1233. http://dx.doi.org/10.1016/j. envint.2009.07.001. PMid:19640587 
FIELD, CB., BEHRENFELD, MJ., RANDERSON, JT. and FALKOWSKI, P., 1998. Primary production of the biosphere: integrating terrestrial and oceanic components. Science, vol. 281, no. 5374, p. 237-240. http://dx.doi.org/10.1126/science.281.5374.237. PMid:9657713

HEO, WM. and KIM, B., 2004. The effect of artificial destratification on phytoplankton in a reservoir. Hydrobiologia, vol. 524, no. 1, p. 229-239. http://dx.doi.org/10.1023/B:HYDR.0000036142.74589.a4.

JÖHNK, KD., HUISMAN, J., SHARPLES, J., SOMMEIJER, B., VISSER, PM. and STROOM, JM., 2008. Summer heatwaves promote blooms of harmful Cyanobacteria. Global Change Biology, vol. 14 , no. 3 , p. $495-512$. http://dx.doi.org/10.1111/j.13652486.2007.01510.x

LINDENSCHMIDT, K. and CHORUS, I., 1998. The effect of water column mixing on phytoplankton succession, diversity and similarity. Journal of Plankton Research, vol. 20, no. 10, p. 1927-1951. http://dx.doi.org/10.1093/plankt/20.10.1927.

LITCHMAN, E., PINTO, PT., KLAUSMEIER, CA., THOMAS, MK. and YOSHIYAMA, K., 2010. Linking traits to species diversity and community structure in phytoplankton. Hydrobiologia, vol. 653, no. 1, p. 15-28. http://dx.doi.org/10.1007/s10750-010-0341-5.

LOBO, E. and LEIGHTON, G., 1986. Estructuras comunitarias de las fitocenosis planctonicas de los sistemas de desembocaduras de rios y esteros de la zona central de Chile. Revista de Biologia Marina, vol. 22, p. 1-29.

LOPES, MRM., BICUDO, CEM. and FERRAGUT, MC., 2005. Short term spatial and temporal variation of phytoplankton in a shallow tropical oligotrophic reservoir, southeast Brazil. Hydrobiologia, vol. 542, no. 1, p. 235-247. http://dx.doi.org/10.1007/ s10750-004-8332-z.

MARINHO, MM. and HUSZAR, VLM., 2002. Nutrient availability and physical conditions as controlling factors of phytoplankton composition and biomass in a tropical reservoir (Southeastern Brazil). Algological Studies. Archiv fuer Hydrobiologie, vol. 153 , no. 3, p. 443-468.

MELLARD, JP., YOSHIYAMA, K., LITCHMAN, E. and KLAUSMEIER, CA., 2011. The vertical distribution of phytoplankton in stratified water columns. Journal of Theoretical Biology, vol. 269, no. 1, p. 16-30. http://dx.doi.org/10.1016/j.jtbi.2010.09.041. PMid:20932846

MOSCHINI-CARLOS, V., BORTOLI, S., PINTO, E., NISHIMURA, P.Y., FREITAS, L.G., POMPÊO, M L.M. and DÖRR, F., 2009. Cyanobacteria and cyanotoxin in the Billings Reservoir (São Paulo, SP, Brazil). Limnetica, vol. 28, no. 2, p. 273-282.

MOURA, AN., DANTAS, EW., OLIVEIRA, HSB. and BITTENCOURT-OLIVEIRA, MC., 2011. Vertical and temporal dynamics of cyanobacteria in the Carpina potable water reservoir in Northeastern Brazil. Brazilian Journal of Biology, vol. 71, no. 2, p. 451-459. http://dx.doi.org/10.1590/S1519-69842011000300015.

OTTEN, TG., XU, H., QIN, B., ZHU, G. and PAERL, HW., 2012. Spatiotemporal patterns and ecophysiology of toxigenic microcystis blooms in Lake Taihu, China: implications for water quality management. Environmental Science \& Technology, vol. 46, no. 6, p. 3480-3488. http://dx.doi.org/10.1021/es2041288. PMid:22324444

PADISÁK, J., 1997. Cylindrospermopsis raciborskii (Woloszynska) Seenayya et Subba Raju, an expanding, highly adaptative cyanobacterium: worldwide distribution and review of its ecology. Algological Studies. Archiv fuer Hydrobiologie, vol. 107, p. 563-593.

PADISÁK, J., TÓTH, LG. and RAJCZY, M., 1988. The role of storms in the summer sucession of the phytoplankton in community in a shallow lake (lake Balaton, Hungary). Journal of Plankton Research, vol. 10, no. 2, p. 249-265. http://dx.doi.org/10.1093/ plankt/10.2.249.

PAYNE, AI., 1986. The ecology of tropical lakes and rivers. Chichester: J Wiley and Sons. $301 \mathrm{p}$.

PERNAMBUCO. Secretaria de Recursos Hídricos - SRH., 2000. Plano Estadual de Recursos Hídricos do Estado de Pernambuco: documento sintese. Recife.

PIELOU, EC., 1977. Mathematical ecology. New York: WileyInterscience. $385 \mathrm{p}$.

POOLE, HH. and ATKINS, WRG., 1929. Photo-electric measurements of submarine ilumination throughout the year. Journal of Marine Biology Association, vol. 16, no. 1, p. 297-324. http://dx.doi.org/10.1017/S0025315400029829.

REYNOLDS, CS., 1997. Vegetation process in the pelagic: a model for ecosystem theory. In KINNE, O. Excellence in ecology. Germany: Ecology Institute, Oldendorf/Luke. p. 3-77.

SALMASO, N., NASELLI-FLORES, L. and PADISÁK, J., 2012. Impairing the largest and most productive forest on our planet: how do human activities impact phytoplankton? Hydrobiologia, vol. 698 , no. 1 , p. 375-384. http://dx.doi.org/10.1007/s10750012-1253-3.

SHANNON, CE. and WEAVER, W., 1948. The mathematical theory of communication. Urbana: Illinois University Press. 117 p.

UTERMÖHL, H., 1958. Zur vervollkommnung der quantitativen phytoplankton-methodik. Mitteilungen Internationale Vereiningung fuer Theoretische und Angewandte Limnologie, vol. 9, p. 1-38.

VALDERRAMA, JC., 1981. The simultaneous analysis of total nitrogen and total phosphorus in natural waters. Marine Chemistry, vol. 10, no. 2, p. 109-122. http://dx.doi.org/10.1016/03044203(81)90027-X.

WALSBY, AE., 2005. Stratification by cyanobacteria in lakes: a dynamic buoyancy model indicates size limitations met by Planktothrix rubescens filaments. The New Phytologist, vol. 168, no. 2, p. 365-376. http://dx.doi.org/10.1111/j.1469-8137.2005.01508.x. PMid:16219076

WOLIN, JA. and DUTHIE, H., 1999. Diatoms as indicators of water level change in freshwater lakes. In STOERMER, E.F. and SMOL, JP. The diatoms: applications for the environmental and earth sciences. Cambridge: Cambridge University Press. p. 183-202. 